\title{
The use of sugammadex for the reversal of neuromuscular blockade after thymectomy with videothoracoscopy in myasthenia gravis patients - a preliminary report
}

\author{
Hanna Misiołek ${ }^{1}$, Damian Czyżewski², Jacek Karpe ${ }^{1}$, Anna Tomala ${ }^{3}$, Piotr Palaczyński ${ }^{4}$, Jacek Chełchowski ${ }^{4}$ \\ ${ }^{1}$ Klinika Anestezjologii i Intensywnej Terapii, Wydział Lekarski z Oddziałem Lekarsko-Dentystycznym w Zabrzu, SUM Katowice \\ ${ }^{2}$ Katedra i Klinika Chirurgii Klatki Piersiowej, Wydział lekarski z Oddziałem Lekarsko-Dentystycznym w Zabrzu, SUM Katowice \\ ${ }^{3}$ Oddział Anestezjologii i Intensywnej Terapii, SP ZOZ Szpital Wielospecjalistyczny, Jaworzno \\ ${ }^{4}$ Koło Naukowe STN przy Klinice Anestezjologii i Intensywnej Terapii, Wydział Lekarski z Oddziałem Lekarsko-Dentystycznym \\ w Zabrzu, SUM Katowice
}

Kardiochirurgia i Torakochirurgia Polska 2013; 10 (3): 239-243

\begin{abstract}
Background: The causal treatment of choice in patients suffering from myasthenia gravis (MG) is thymectomy. The use of neuromuscular blocking agents during surgery carries a risk of prolonged postoperative intubation and mechanical ventilation. Recently, a new agent for reversing neuromuscular blockade has been included in clinical practice - sugammadex. Sugammadex is a modified gamma-cyclodextrin, which coats and inactivates the molecules of neuromuscular blocking agents. The created complexes are then removed by the kidneys. The aim of the study was to evaluate the usefulness of sugammadex in reversing neuromuscular blockade generated by rocuronium during thymectomy in MG patients.

Material and methods: Twenty-two MG patients who underwent minimally invasive thymectomy were divided into two groups, depending on the drug used for reversing neuromuscular blockade ( $\mathrm{S}$ - sugammadex vs. $\mathrm{P}$ - polstigminum). The monitoring of the neuromuscular blockade enabled the use of proper doses of rocuronium, as well as of the neuromuscular blockade reversing drugs. The time from the administration of rocuronium to blockade achievement (TO), time from the administration of the blockade reversing drug to the return of sufficient spontaneous breathing and extubation (T1), and duration of the surgery (T2) were evaluated. Blood pressure, pulse, and pulse oximetry were recorded at four time-points during surgery. The protocol of anesthesia was uniform in the two groups, and it included the induction and maintenance of total intravenous anesthesia and epidural thoracic analgesia with the use of bupivacaine.

Results: There were no differences between the groups in terms of demographic and hemodynamic parameters or the used doses of the neuromuscular blocking drugs. The mean
\end{abstract}

\section{Streszczenie}

Wstęp: Leczeniem przyczynowym chorych z nużliwością mięśniową (ang. myasthenia gravis - MG) jest z wyboru usunięcie grasicy. U pacjentów z MG zastosowanie środków zwiotczających w celu przeprowadzenia operacji stanowi zagrożenie przedłużonej intubacji i wentylacji mechanicznej w okresie pooperacyjnym. Największym odkryciem ostatnich lat w anestezjologii jest środek odwracający blokadę nerwowo-mięśniową o nazwie sugammadeks. Preparat jest modyfikowaną gamma-cyklodekstryną, która opłaszcza i inaktywuje cząsteczki środków zwiotczających, tworząc z nimi kompleksy wydalane następnie przez nerki.

Celem pracy była ocena użyteczności sugammadeksu w odwróceniu blokady nerwowo-mięśniowej wywołanej rokuronium po operacjach usunięcia grasicy u pacjentów z MG.

Materiał i metody: Dwudziestu dwóch chorych z MG poddanych małoinwazyjnej operacji usunięcia grasicy podzielono na 2 grupy w zależności od użytego środka odwracającego zwiotczenie mięśni poprzecznie prążkowanych (S-sugammadeks vs. P-polstygmina). Monitorowanie głębokości blokady nerwowo-mięśniowej umożliwiło prawidłowe dawkowanie zarówno rokuronium, jak i środków odwracających blokadę nerwowo-mięśniową. Ocenie poddano czas od podania rokuronium do uzyskania blokady (TO), od podania środka odwracającego blokadę do powrotu wydolnego oddechu i ekstubacji (T1) oraz czas trwania zabiegu (T2). Oceniano wartości ciśnień tętniczych, skurczów serca i pulsoksymetrii w czterech punktach czasowych. Protokół znieczulenia w obu grupach zawierat indukcję i podtrzymanie znieczulenia metodą anestezji całkowicie dożylnej; analgezję zapewniono metodą zewnątrzoponową w odcinku piersiowym, z użyciem bupiwakainy.

Address for correspondence: prof. dr hab. med. Hanna Misiołek, Klinika Anestezjologii i Intensywnej Terapii, Szpital Kliniczny Nr 1 im. Prof. St. Szyszko, 41-800 Zabrze ul. 3 Maja 13-15, phone/fax: 3237045 83, 32370 45 96, e-mail: hanna.misiolek@gmail.com 
time from the administration of the agent reversing the neuromuscular blockade to the achievement of sufficient spontaneous breathing and extubation was significantly shorter in the $\mathrm{S}$ group in comparison to the $\mathrm{P}$ group.

Conclusions: Sugammadex is a safe and effective agent reversing neuromuscular blockades achieved with rocuronium in MG patients.

Key words: sugammadex, myasthenia gravis, videothoracoscopy.

\section{Introduction}

Myasthenia gravis (MG) is a neuromuscular disease associated with the presence of antibodies against nicotinic acetylcholine receptors in the postsynaptic membrane of the neuromuscular junction, which reduce the conduction of nerve impulses, leading to the weakening and fatigability of muscles. Myasthenia has become more prevalent and widespread, which is confirmed by the approximate total incidence of 5.3 per 1 million person-years and the approximate total prevalence of 77.7 per 1 million, which may be caused by improved diagnostics and treatment methods. The disease not only affects young women, but also impacts a substantial percentage of the older population, in which it is diagnosed too rarely [1-3].

The cause of myasthenia still remains unknown, but in many cases there seems to be an association between myasthenia and thymus function. The presence of antibodies against nicotinic acetylcholine receptors (nAChR) or antibodies against muscle-specific tyrosine kinase (MuSK), found in $80-85 \%$ of patients, confirms the disease in conjunction with clinical symptoms. In the majority of nAChRpositive patients, the thymus exhibits characteristic changes in its structure, or thymoma is diagnosed. The treatment of choice is thymectomy, which results in the improvement of the patient's condition or even complete symptom abatement. MG patients undergoing the removal of a persistent thymus constitute a special group of patients in whom the use of neuromuscular blocking agents to perform the surgery causes the risk of prolonged intubation and mechanical ventilation in the postoperative period $[4,5]$.

Recently, a new agent for reversing neuromuscular blockade has been included in clinical practice - sugammadex (Bridion, MSD, USA). It is the first and, so far, the only preparation belonging to a new group of chemical agents known as SRBAs (selective relaxant binding agents), which selectively bind steroidal neuromuscular blockers (rocuronium, vecuronium). This agent is a modified gammacyclodextrin, which coats and inactivates the molecules of compounds with steroid rings, including neuromuscular blockers, creating complexes which are subsequently removed by the kidneys [6, 7].

Sugammadex captures and isolates the muscle relaxing agent present in the plasma and tissues, decreasing
Wyniki: Chorzy nie różnili się w obu grupach pod względem parametrów demograficznych, hemodynamicznych oraz zastosowanej ilości środka zwiotczającego. Znamiennie krótszy czas od podania środka odwracającego blokadę do wydolnego oddechu i ekstubacji odnotowano w grupie S w porównaniu $z$ grupą $P$.

Wniosek: Dla pacjentów z MG sugammadeks jest użytecznym i bezpiecznym środkiem odwracającym blokadę nerwowo-mięśniową wywołaną rokuronium.

Słowa kluczowe: sugammadeks, myasthenia gravis, wideotorakoskopia.

its concentration. This results in the detachment of the remaining molecules of the agent from the nicotinic receptors and their further inactivation. The postsynaptic receptors once again become available for acetylcholine. The binding of neuromuscular blockers by cyclodextrins takes place in a $1: 1$ ratio, with the highest affinity for rocuronium, lower for vecuronium, and the lowest for pancuronium. A correct dose of sugammadex reverses neuromuscular blockade regardless of its depth. Its action does not interfere with the metabolism of acetylcholine; therefore, it does not require the use of anticholinergic drugs, eliminating the risk of their side-effects [8-10].

\section{Aim of the study}

The aim of the study was to assess the usefulness of sugammadex in reversing neuromuscular blockades achieved with rocuronium in MG patients.

\section{Material and methods}

This prospective, randomized study was approved by the Bioethics Committee of the Medical University of Silesia. The study initially included 22 patients with diagnosed MG who were qualified for causal treatment, i.e., surgical thymectomy with video-assisted thoracoscopy.

In both groups, rocuronium bromide was used for the relaxation of striated muscles (Esmeron, injectable solution, $10 \mathrm{mg} / \mathrm{ml}$ i.v., Organon Netherlands) at a dose of $10-25 \%$ of the regular dose, i.e. c. $0.1-0.25 \mathrm{mg} / \mathrm{kg} \mathrm{BM}$.

In group $\mathrm{P}(N=9)$, neostigmine was used to reverse the neuromuscular blockade (Polstigminum, injection, $0.5 \mathrm{mg} / \mathrm{ml}$, TEVA Pharmaceuticals Poland) at a dose of $1-2.5 \mathrm{mg}$ i.v.

In group $S(N=13)$, the neuromuscular blockade was reversed using sugammadex (Bridion 100 mg/ml, Organon Netherlands) at a dose of 2-4 mg/kg BM.

In order to assess the return of neuromuscular conduction after the use of rocuronium, stimulation with four stimuli (TOF - train-of-four) was employed, establishing the ratio between the fourth stimulus response (T4) and the first stimulus response (T1) (TOFr - train-of-four ratio). A TOF GUARD monitor (TOF-Watch SX, Organon Ireland Ltd., a division of Merck and Co., Inc., Swords County, Dublin, Ireland) was used for the examination. The drug 
reversing the neuromuscular blockade was administered after achieving TOFr $=0.45$, while the value of TOFr $>0.9$, indicating a sufficient return of neuromuscular conduction, constituted the criterion for safe extubation and residual blockade reversal.

In all patients, the time from the administration of rocuronium to blockade achievement (TO in seconds) was assessed, along with the time from the administration of the blockade reversing drug to the return of sufficient spontaneous breathing and extubation (T1 in seconds) and the duration of the procedure (T2 in seconds). The dose of rocuronium necessary to maintain muscle relaxation at the level of $25-50 \%$ of TOF cycle responses was also recorded.

The constant monitoring of the circulatory system parameters (heart rate, systolic, diastolic, and mean arterial pressure, as well as arterial blood saturation measured by means of pulse oximetry) ensured the patient's safety during surgery and helped manage all potential undesired events. For the purpose of statistical analysis, the above-mentioned measurement values were recorded at four time-points ( 1 - before the induction of anesthesia, 2 - after intubation, 3 - after thymectomy, 4 - after extubation). The protocol of anesthesia was uniform in the two groups and included the induction and maintenance of total intravenous anesthesia (TIVA) using propofol (Plofed $1 \%$, Polfa Warsaw). First, it was administered at an initial dose of $2 \mathrm{mg} / \mathrm{kg} \mathrm{BM}$, next $10 \mathrm{mg} / \mathrm{kg} \mathrm{BM} / \mathrm{h}$ for 10 minutes through an infusion pump, then $8 \mathrm{mg} / \mathrm{kg}$ of $\mathrm{BM} / \mathrm{h}$ for another 10 minutes, ultimately achieving a flow of $6 \mathrm{mg} / \mathrm{kg}$ of $\mathrm{BM} / \mathrm{h}$ until the end of the procedure. Analgesia was established by means of thoracic epidural administration of bupivacaine (Marcaine $0.5 \%$, AstraZeneca AB, Sweden) at a volume of 6-8 $\mathrm{ml}$, in a $0.25 \%$ solution.

Patients aged 18-75 with normal BMI, diagnosed with MG of type Ila or Ilb on the Osserman scale, qualified for the removal of persistent thymus through video-assisted thoracoscopy, were included in the study after providing their informed consent.

The exclusion criteria were the following: lack of consent, age under 18 and over 75, obesity, renal or liver insufficiency, oversensitivity to propofol and contraindications for thoracic epidural anesthesia (anatomical and technical difficulties in blockade execution and blood clotting disorders), or the necessity of conversion from minimally invasive surgery to methods involving thoracotomy or sternotomy.

\section{Statistical analysis}

The statistical analysis was performed using the Statistica 10.0 PL software. In order to compare the studied parameters, Student's $t$-test for independent variables or analysis of variance (ANOVA) for repeated measurements with the post-hoc RIR Tukey test was used for values with normal distribution. For values with distribution other than normal, the Mann-Whitney $U$ test or Kruskal-Wallis test was utilized. The results were presented as mean values with standard deviation or a 95\% confidence interval; $p<0.05$ was considered to be statistically significant.

\section{Results}

The patients in the studied groups did not differ with respect to demographic parameters. The total mean dose of rocuronium was comparable in the two groups (Table I). The mean time from the administration of the agent reversing the neuromuscular blockade to extubation (T1 in seconds) was significantly shorter in the group of patients receiving sugammadex in comparison to the polstigmine group (35.00 \pm 22.17 vs. $174.29 \pm 38.67, p<0.0001)$ (Table II). The time from the administration of rocuronium to the achievement of the blockade and the duration of the procedure were comparable (Table II). The patients in the study groups were stable with regard to hemodynamic parameters and arterial blood oxygenation, and the values of the measured parameters were similar (Tables III-VI).

\section{Discussion}

Because of the decreased number of normal nicotinic acetylcholine receptors, patients suffering from MG react differently to various neuromuscular blockers. Patients treated with cholinesterase inhibitors, for example Mestinon (pyridostigmine), may experience prolonged blockade after the use of succinylcholine because of the simultaneous inhibition of plasma cholinesterase. In turn, when the therapy of MG patients is conducted without the use of cholinesterase inhibitors, resistance to succinylcholine may arise because of the lack of a sufficient number of nAChRs, which are nec-

Tab. I. Demographic data

\begin{tabular}{lccc} 
& $\begin{array}{c}\text { Group } S(N=13) \\
\text { mean } \pm \text { SD }\end{array}$ & $\begin{array}{c}\text { Group P }(N=9) \\
\text { mean } \pm S D\end{array}$ & $P$ \\
\hline Age (years) & $44.46 \pm 17.88$ & $41.5 \pm 15.41$ & 0.723 \\
\hline Body mass $(\mathrm{kg})$ & $71.92 \pm 20.54$ & $72.07 \pm 14.68$ & 0.987 \\
\hline Height $(\mathrm{cm})$ & $167.77 \pm 8.22$ & $170.71 \pm 4.72$ & 0.397 \\
\hline BMl & $25.53 \pm 7.03$ & $24.57 \pm 3.88$ & 0.744 \\
\hline $\begin{array}{l}\text { Total dose of rocu- } \\
\text { ronium }(\mathrm{mg})\end{array}$ & $38.85 \pm 15.30$ & $40.71 \pm 11.34$ & 0.781 \\
\hline
\end{tabular}

Tab. II. TO, T1, and T2 times in the studied groups

\begin{tabular}{lccc} 
& $\begin{array}{c}\text { Group } S(N=13) \\
\text { mean } \pm S D\end{array}$ & $\begin{array}{c}\text { Group P }(N=9) \\
\text { mean } \pm S D\end{array}$ & $P$ \\
$\begin{array}{l}\text { T0 }- \text { time from the administration of rocuronium to the achievement of } \\
\text { blockade }(s)\end{array}$ & $86.15 \pm 31.24$ & $86.43 \pm 26.25$ & 0.984 \\
\hline $\begin{array}{l}\text { T1 - time from the administration of the blockade reversing agent to } \\
\text { extubation }(\mathrm{s})\end{array}$ & $35.00 \pm 22.17$ & $174.29 \pm 38.67$ & 0.000 \\
\hline T2 - duration of surgery (min) & $66.08 \pm 23.36$ & $55.00 \pm 13.23$ & 0.265 \\
\hline
\end{tabular}


Tab. III. Systolic blood pressure (SBP) at selected time-points

\begin{tabular}{lccc} 
& $\begin{array}{c}\text { Group S }(N=13) \\
\text { mean } \pm S D\end{array}$ & $\begin{array}{c}\text { Group } P(N=9) \\
\text { mean } \pm S D\end{array}$ & $P$ \\
SBP 1 $(\mathrm{mm} \mathrm{Hg})$ & $136.92 \pm 23.14$ & $134.29 \pm 16.18$ & 0.793 \\
\hline SBP 2 $(\mathrm{mm} \mathrm{Hg})$ & $125.77 \pm 27.45$ & $122.14 \pm 20.79$ & 0.764 \\
\hline SBP 3 $(\mathrm{mm} \mathrm{Hg})$ & $119.23 \pm 16.94$ & $117.14 \pm 17.29$ & 0.797 \\
\hline SBP 4 $(\mathrm{mm} \mathrm{Hg})$ & $124.62 \pm 21.36$ & $122.86 \pm 14.96$ & 0.849 \\
\hline
\end{tabular}

Tab. IV. Diastolic blood pressure (DBP) at selected time-points

\begin{tabular}{lccc} 
& $\begin{array}{c}\text { Group } S(N=13) \\
\text { mean } \pm \text { SD }\end{array}$ & $\begin{array}{c}\text { Group } P(N=9) \\
\text { mean } \pm S D\end{array}$ & $P$ \\
DBP 1 $(\mathrm{mm} \mathrm{Hg})$ & $85.77 \pm 14.98$ & $82.86 \pm 12.86$ & 0.669 \\
\hline DBP 2 $(\mathrm{mm} \mathrm{Hg})$ & $77.69 \pm 16.78$ & $76.43 \pm 17.49$ & 0.876 \\
\hline DBP 3 $(\mathrm{mm} \mathrm{Hg})$ & $74.62 \pm 17.85$ & $76.43 \pm 10.29$ & 0.809 \\
\hline DBP 4 $(\mathrm{mm} \mathrm{Hg})$ & $76.92 \pm 14.51$ & $79.29 \pm 16.94$ & 0.747 \\
\hline
\end{tabular}

Tab. V. Heart rate (HR) at selected time-points

\begin{tabular}{lccc} 
& $\begin{array}{c}\text { Group S }(N=13) \\
\text { mean } \pm \text { SD }\end{array}$ & $\begin{array}{c}\text { Group P }(N=9) \\
\text { mean } \pm S D\end{array}$ & $P$ \\
HR 1 $(/ \mathrm{min})$ & $87.31 \pm 18.21$ & $80.71 \pm 9.76$ & 0.388 \\
\hline HR 2 $(/ \mathrm{min})$ & $90.38 \pm 13.76$ & $80.00 \pm 8.16$ & 0.086 \\
\hline HR 3 $(/ \mathrm{min})$ & $79.23 \pm 8.62$ & $77.14 \pm 10.75$ & 0.641 \\
\hline HR 4 $(/ \mathrm{min})$ & $81.15 \pm 15.16$ & $79.29 \pm 8.86$ & 0.769 \\
\hline
\end{tabular}

Tab. VI. Arterial blood saturation as measured by pulse oximetry $\left(\mathrm{Sat} \mathrm{O}_{2}\right)$ at selected time-points

\begin{tabular}{lccc} 
& $\begin{array}{c}\text { Group } \mathrm{S}(\mathrm{N}=13) \\
\text { mean } \pm \mathrm{SD}\end{array}$ & $\begin{array}{c}\text { Group } \mathrm{P}(\mathrm{N}=9) \\
\text { mean } \pm \mathrm{SD}\end{array}$ & $P$ \\
\hline Sat $\mathrm{O}_{2} 1(\%)$ & $98.15 \pm 1.63$ & $98.57 \pm 0.79$ & 0.533 \\
\hline Sat $\mathrm{O}_{2} 2(\%)$ & $98.38 \pm 1.85$ & $99.43 \pm 0.79$ & 0.175 \\
\hline Sat $\mathrm{O}_{2} 3(\%)$ & $97.46 \pm 3.18$ & $99.00 \pm 1.00$ & 0.233 \\
\hline${\text { Sat } \mathrm{O}_{2} 4(\%)}$ & $98.15 \pm 1.77$ & $99.14 \pm 0.90$ & 0.187 \\
\hline
\end{tabular}

essary for depolarization. On the other hand, sensitivity to non-depolarizing blocking agents is higher due to the reduced number of receptors. Attempts of blockade reversal in patients treated with cholinesterase inhibitors may fail as a result of a complete acetylcholinesterase block [11, 12].

Therefore, the selection of an adequate blocking agent, its dosage, and the necessity of a complete reversal of its effects constitute the key elements in the anesthesia of MG patients.

Tripathi et al. [13] demonstrated that omitting one dose of Mestinon before surgery increases the effectiveness of non-depolarizing blocking agents and enables their use in smaller doses; however, it raises the risk of pulmonary complications. According to the study protocol, in line with the current neurological guidelines, the patients received the last dose of Mestinon in the evening, which, according to Tripathi's theory, enabled the achievement of muscle relaxation with small doses of rocuronium. Thus, the reversal of the blockade could be accomplished with minimal doses of sugammadex.
The anesthesia protocol developed in our center, where the number of MG patients undergoing surgery is relatively high, involves the use of total intravenous anesthesia in conjunction with central blockade, without employing any inhaled agents [14]. The standards developed on the basis of in-house studies are in accordance with the suggestions of many authors, whose research indicates that myasthenia patients are more sensitive to the "relaxing" effect of inhaled agents $[15,16]$.

In turn, epidural anesthesia provides better postoperative management of pain and respiratory function, and may significantly reduce the dosage of blocking agents, thus decreasing the dosage of drugs used for reversing neuromuscular blockade [17-19]. The conclusions of the cited authors are confirmed by the results of our in-house studies, in which low doses of muscle relaxants were employed, and unprecedentedly low doses of sugammadex were used to effectively reverse the blockade.

Sugammadex binds with the free molecules of rocuronium, reducing their number and, as a result, inactivating them. This enables the reversal of neuromuscular blockade in less than 3 minutes without any influence on nAChRs or cholinesterase inhibitors. The use of sugammadex in individual myasthenia patients has been described in several publications within the last two years. Their authors observed rapid blockade reversal achieved with the rocuronium-sugammadex combination; no side-effects or postoperative complications have been revealed [20-23].

The significantly shorter time period between the administration of sugammadex and extubation, in comparison to polstigmine, was not surprising for the authors of the present work. Studies comparing these two blockade reversing agents in patients without $M G$ indicated that the administration of sugammadex at a dose of $2 \mathrm{mg} \mathrm{kg}^{-1}$ reversed moderate rocuronium blockades significantly faster than neostigmine at a dose of $50 \mu \mathrm{g} \mathrm{kg}^{-1}$. In the first case, TOFr 0.9 was achieved after 1.9 minutes, and in the second, after 17.6 minutes. In both cases, no residual curarization took place [7].

In our work, the study was not completed in two female patients in whom polstigmine was employed; the return of muscle strength enabling sufficient breathing was not achieved. After one day at the intensive care unit, including 6 hours of mechanical ventilation, the patients left the hospital as planned without any complications.

Thanks to diligent preparation and detailed preoperative examination, adherence to the established daily dosage of Mestinon (omitting one dose on the night before the operation), the monitoring of the motor blockade level and basic life functions during anesthesia, the use of blockade reversing agents, extubation after the achievement of sufficient breathing, as well as postoperative analgesia, it is possible to minimize the necessity of postoperative mechanical ventilation in MG patients. The authors of the present work are continuing their research in this field in order to increase the number of studied patients and verify the results presented in this preliminary report, which, in 
the view of the authors, will be unique in the available literature.

\section{Conclusions}

Sugammadex is a safe and effective agent reversing neuromuscular blockades achieved with rocuronium in MG patients.

\section{References}

1. Carr AS, Cardwell CR, McCarron PO, McConville J. A systemic review of population based epidemiological studies in myasthenia gravis. BMC Neurol 2010; 10: 1-9.

2. Vincent A, Clover L, Buckley C, Grimley Evans J, Rothwell PM, the UK Myasthenia Gravis Survey. Evidence of underdiagnosis of myasthenia gravis in older people. J Neurol Neurosurg Psychiatry 2003; 74: 1105-1108.

3. Gold R, Hohlfeld R, Toyka KV. Progress in the treatment of myasthenia gravis. Ther Adv Neurol Disord 2008; 1: 36-51.

4. Gronseth GS, Barohn RJ. Practice parameter: thymectomy for autoimmune myasthenia gravis (an evidence-based review): report of the quality standards subcommittee of the American Academy of Neurology. Neurology 2000; 55: 7-15

5. Farrugia ME, Vincent A. Autoimune mediated neuromuscular junction defects. Curr Opin Neurol 2010; 23: 489-495.

6. Booij LH, van Egmond J, Driessen JJ, de Boer HD. In vivo animal studies with sugammadex. Anaesthesia 2009; 64 (Suppl. 1): 38-44.

7. Mirakhur RK. Sugammadex in clinical practice. Anaesthesia 2009; 64 (Suppl. 1): 45-54.

8. Booij LH. Cyclodextrins and the emergence of sugammadex. Anaesthesia 2009; 64 (Suppl. 1): 31-37.

9. Gijsenbergh F, Ramael S, Houwing N, van lersel T. First human exposure of Org 25969, a novel agent to reverse the action of rocuronium bromide. Anesthesiology 2005; 103: 695-703.

10. Glinka L, Onichimowski D, Sieniuta P, Korecki A. Sugammadex - two years in clinical practice. Anesthesiol Intensive Ther 2010; 42: 155-159.
11. Wainwright AP, Brodrick PM. Suxamethonium in myasthenia gravis. Anaesthesia 1987; 42: 950-957.

12. Eisenkraft JB, Jeffrey Book W, Papatestas AE. Sensitivity tovecuronium in myasthenia gravis: a dose-response study. Can J Anaesth 1990; 37: 301-306.

13. Tripathi M, Kaushik S, Dubey P. The effect of use of pyridostigmine and requirement of vecuronium in patients with myasthenia gravis. J Postgrad Med 2009; 49: 311-315.

14. Misiołek H, Kucia H, Karpe J, Stoksik P, Knapik P, Wojcieszek E, Czyżewski D, Werszner M. Znieczulenie chorych z myasthenia gravis do zabiegu usunięcia grasicy metodą wideotorakoskopii - doświadczenia własne. Anest Inten Ter 2002; 2: 117-120.

15. Kiran U, Choudhury M, Saxena N, Kapoor P. Sevoflurane as a sole anaesthetic for thymectomy in myasthenia gravis. Acta Anaesthesiol Scand 2000; 44: 351-353.

16. Nitahara K, Sugi Y, Higa K, Shono S, Hamada T. Neuromuscular effects of sevoflurane in myasthenia gravis patients. BJ Anaesth 2007; 98: 337-341.

17. Mekis D, Kamenik M. Remifentanil and high thoracic epidural anaesthesia: a successful combination for patients with myasthenia gravis undergoing transsternal thymectomy. Eur J Anaesthesiol 2005; 22: 392-399.

18. Bagshaw O. A combination of total intravenous anesthesia and thoracic epidural for thymectomy in juvenile myasthenia gravis. Pediatr Anesth 2007; 17: 370-374.

19. Tsunezuka Y, Oda M, Matsumoto I, Tamura M, Watanabe G. Extended thymectomy in patients with myasthenia gravis with high thoracic epidural anesthesia alone. World J Surg 2004; 28: 962-966.

20. Unterbuchner $\mathrm{C}$, Fink $\mathrm{H}$, Blobner $\mathrm{M}$. The use of sugammadex in a patient with myasthenia gravis. Anaesthesia 2010; 65: 302-305.

21. De Boer HD, van Egmond J, Driessen JJ, Booij LH. A new approach to anesthesia management in myasthenia gravis: reversal of neuromuscular blockade by sugammadex. Rev Esp Anestesiol Reanim 2010; 57: 181-184.

22. Petrun AM, Mekis D, Kamenik M. Successful use of rocuronium and sugammadex in a patient with myasthenia. Eur J Anaesthesiol 2010; 27: 917-918.

23. Jakubiak J, Gaszyński T, Gaszyński W. Neuromuscular block reversal with sugammadex in a morbidly obese patient with myasthenia gravis. Anesthesiol Intensive Ther 2012; 44: 28-30. 